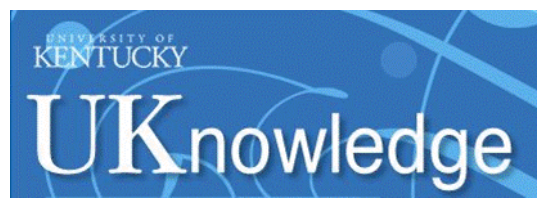

University of Kentucky UKnowledge

10-3-2006

\title{
Aluminum Bioavailability from the Approved Food Additive Leavening Agent Acidic Sodium Aluminum Phosphate, Incorporated into a Baked Good, Is Lower than from Water
}

Robert A. Yokel

University of Kentucky, ryokel@email.uky.edu

Rebecca L. Florence

University of Kentucky

Right click to open a feedback form in a new tab to let us know how this document benefits you. Follow this and additional works at: https://uknowledge.uky.edu/ps_facpub

Part of the Pharmacy and Pharmaceutical Sciences Commons 


\section{Aluminum Bioavailability from the Approved Food Additive Leavening Agent Acidic Sodium Aluminum Phosphate, Incorporated into a Baked Good, Is Lower than from Water}

Digital Object Identifier (DOI)

https://doi.org/10.1016/j.tox.2006.07.014

Notes/Citation Information

Published in Toxicology, v. 227, issues 1-2.

Copyright @ 2006 Elsevier Ireland Ltd.

(C) 2006. This manuscript version is made available under the CC-BY-NC-ND 4.0 license https://creativecommons.org/licenses/by-nc-nd/4.0/.

The document available for download is the authors' post-peer-review final draft of the article. 
Aluminum bioavailability from the approved food additive leavening agent acidic sodium aluminum phosphate, incorporated into a baked good, is lower than from water

\author{
Robert A. Yokel ${ }^{a, b}$ and Rebecca L. Florence ${ }^{a}$ \\ aPharmaceutical Sciences Department, College of Pharmacy, University of Kentucky Medical \\ Center, 725 Rose Street, Lexington, KY 40536-0082, USA ${ }^{b}$ Graduate Center for Toxicology, \\ University of Kentucky Medical Center, Lexington, KY 40536-0082, USA
}

Corresponding author:

Robert A. Yokel, Ph.D.

511C Pharmacy Building

725 Rose Street

University of Kentucky Medical Center

Lexington, KY 40536-0082

phone: 859-257-4855

fax: 859-323-6886

e-mail: ryokel@email.uky.edu

Short title: Al bioavailability from acidic SALP 


\section{Abstract}

There are estimates of oral aluminum (Al) bioavailability from drinking water, but little information on Al bioavailability from foods. Foods contribute $~ 95 \%$ and drinking water 1 to $2 \%$ of the typical human's daily Al intake. The objectives were to estimate oral Al bioavailability from a representative food containing the food additive acidic sodium aluminum phosphate (acidic SALP), a leavening agent in baked goods. Rats were acclimated to a special diet that resulted in no stomach contents $14 \mathrm{~h}$ after its withdrawal. They were trained to rapidly consume a biscuit containing $1.5 \%$ acidic SALP. Oral Al bioavailability was then determined from a biscuit containing 1 or $2 \%$ acidic SALP, synthesized to contain ${ }^{26} \mathrm{Al}$. The rats received concurrent ${ }^{27} \mathrm{Al}$ infusion. Blood was repeatedly withdrawn and serum analyzed for ${ }^{26} \mathrm{Al}$ by accelerator mass spectrometry. Total Al was determined by atomic absorption spectrometry. Oral ${ }^{26} \mathrm{Al}$ bioavailability was determined from the area under the ${ }^{26} \mathrm{Al}$, compared to ${ }^{27} \mathrm{Al}$, serum concentration $\times$ time curves.

Oral Al bioavailability (F) from biscuit containing 1 or $2 \%$ acidic ${ }^{26} \mathrm{Al}-\mathrm{SALP}$ averaged 0.11 and $0.13 \%$; significantly less than from water, which was previously shown to be $\sim 0.3 \%$. The time to maximum serum ${ }^{26} \mathrm{Al}$ concentration was 4.2 and $6 \mathrm{~h}$ after consumption of biscuit containing 1 or $2 \%{ }^{26} \mathrm{Al}$-acidic SALP, respectively, compared to 1 to $2 \mathrm{~h}$ following ${ }^{26} \mathrm{Al}$ in water.

These results of oral AI bioavailability from acidic ${ }^{26} \mathrm{AI}-\mathrm{SALP}$ in a biscuit $(\mathrm{F} \sim 0.1 \%)$ and results from ${ }^{26} \mathrm{Al}$ in water $(\mathrm{F} \sim 0.3 \%) \times$ the contributions of food and drinking water to the typical human's daily Al intake ( 5 to $10 \mathrm{mg}$ from food and $0.1 \mathrm{mg}$ from water, respectively) suggest food provides $\sim 25$-fold more Al to systemic circulation, and potential Al body burden, than does drinking water. 
Keywords: Accelerator mass spectrometry; Acidic sodium aluminium phosphate; Aluminum; Atomic absorption Spectrometry; Food additive; Oral bioavailability; Rat 


\section{Introduction}

Aluminum (Al) can produce toxicity to the central nervous, skeletal and hematopoietic systems. It can produce an encephalopathy in renal-impaired humans (dialysis encephalopathy), cognitive deficits in young children, a low-turnover bone disease, a microcytic hypochromic anemia, and has been controversially implicated as an environmental factor that may contribute to some neurodegenerative diseases, including Alzheimer's disease (Alfrey et al., 1976; Bushinsky, 1997; Yokel, 2000; Gupta et al., 2005; Kawahara, 2005).

The primary oral source of Al in the U.S. for the typical human is foods, contributing $\sim 5$ to $10 \mathrm{mg}$ of Al daily, whereas drinking water provides $\sim 0.1 \mathrm{mg}$ of $\mathrm{Al}$ (Yokel and McNamara, 2001). Different food sources contribute variable amounts of Al to the human diet (Pennington, 1987; UK MAFF, 1993; Lopez et al., 2002). FDA-approved, generally recognized as safe (GRAS) (21 CFR 121.1), food additives are the major source of dietary Al in the U.S. They increase the low inherent level of Al in food by about five-fold (Humphreys and Bolger, 1997). The approved uses of $\mathrm{Al}$ as a food additive in the U.S., Canada and the U.K. are as firming agents, carriers, coloring agents, anti-caking agents, buffers, neutralizing agents, dough strengtheners, emulsifying agents, stabilizers, thickeners, leavening agents, curing agents and texturizers (UK MAFF, 1993; Nieboer et al., 1995). These additives are approved for use in milk, processed cheese, yogurt, preserves, jams and jellies, baking soda, sugars, cereals, flours, grains and powdered or crystalline desert products (Nieboer et al., 1995). The two most quantitatively significant food additives containing Al are acidic sodium aluminum phosphate (SALP; a leavening agent in baked goods) and basic SALP (an emulsifying agent in processed cheese) (Katz et al., 1984; Humphreys and Bolger, 1997; Saiyed and Yokel, 2005). Surveys of daily dietary Al intake suggested adults in the U.S. consumed $\sim 7$ to $9 \mathrm{mg}$ Al daily, depending on age and sex (Pennington and Schoen, 1995) and adults in the U.K. consumed $3.9 \mathrm{mg} \mathrm{Al}$ daily (UK MAFF, 1993). There have been 12 estimates of dietary Al consumption by adults published in the past 10 years from other countries. Most reported equal or less daily Al intake 
than in the U.S. The lower daily Al intakes in some countries, such as in Europe, have been attributed to less use of $\mathrm{Al}$ as a food additive (Müller et al., 1998).

The oral bioavailability of Al has been estimated in a number of studies. The primary interest has been to model drinking water Al consumption and to determine the effect of citrate and silicate on oral Al bioavailability. These are briefly reviewed in the Discussion. It has been suggested that Al bioavailability from water is greater than from food (Martyn et al., 1989). The proposed basis for this is the presence of organic ligands such as phytates and polyphenols in food that are suggested to complex Al and inhibit its oral absorption.

The extent of oral absorption (bioavailability) of hydrophilic substances is generally determined by a comparison of areas under the concentration $(A \cup C) \times$ time curve for the test substance given po and iv. This can be accomplished when the test substance is given as two analytically distinguishable, but biologically indifferent, chemical species at the same time by the po and iv routes. This was the method employed in the present study to estimate oral Al bioavailability from a model food, a biscuit, which contained acidic SALP that was prepared with ${ }^{26} \mathrm{Al}$ as a tracer. ${ }^{26} \mathrm{Al}$ was analyzed by accelerator mass spectrometry (AMS). The use of ${ }^{26} \mathrm{Al}$ in the study of Al toxicokinetics has been reviewed (Flarend and Elmore, 1998). As there is no measurable ${ }^{26} \mathrm{Al}$ in the environment or in normal biological organisms, this approach avoids the interference of endogenous $\mathrm{Al}$ in the study of $\mathrm{Al}$ pharmacokinetics. AMS measures the ratio of ${ }^{26} \mathrm{Al}$ compared to ${ }^{27} \mathrm{Al}$ with a detection limit of ${ }^{26} \mathrm{Al} /{ }^{27} \mathrm{Al}$ of $\sim 10^{-14}$. In the presence of $4 \mathrm{mg}{ }^{27} \mathrm{Al}$, as used in the present study, this represents $\sim 4 \times 10^{-17} \mathrm{~g}$ of ${ }^{26} \mathrm{Al}$, or $\sim 1,000,000$ atoms. Therefore, by utilizing ${ }^{26} \mathrm{Al}$ analyzed by AMS, pharmacokinetic studies of $\mathrm{Al}$ can be conducted at physiological concentrations. As there are negligible chemical differences between ${ }^{26} \mathrm{Al}$ and ${ }^{27} \mathrm{Al}$ they should be handled indistinguishably in vivo. This presents the opportunity to concurrently administer two Al isotopes and differentially analyze them in the same sample utilizing AMS for ${ }^{26} \mathrm{Al}$ and electrothermal atomic absorption spectrometry for ${ }^{27} \mathrm{Al}$, when ${ }^{26} \mathrm{Al}$ provides an insignificant contribution to total Al. This approach was used in the present study. 


\section{Methods}

\subsection{Materials}

Details of the preparation and characterization of the acidic SALP containing ${ }^{26} \mathrm{Al}$ (acidic ${ }^{26} \mathrm{Al}-\mathrm{SALP}$ ) were described (Yokel et al., 2005). ${ }^{26} \mathrm{Al}$ was provided by the Purdue Rare Isotope Measurement Laboratory (PRIME Lab), supplied in $0.01 \mathrm{~N} \mathrm{HCl}$ containing $8.25 \mathrm{nCi}$ (434 ng) ${ }^{26} \mathrm{Al} / \mathrm{ml}$ and with a $34: 1{ }^{27} \mathrm{Al}:{ }^{26} \mathrm{Al}$ ratio yielding $15.2 \mu \mathrm{g}$ total $\mathrm{Al} / \mathrm{ml}$. Briefly, $\mathrm{Al}(\mathrm{OH})_{3}$ containing ${ }^{26} \mathrm{Al}$ was prepared and was characterized by near infrared spectroscopy. It was incorporated into the synthesis of acidic SALP by the method of McDonald (1951). The acidic SALP was characterized by near infrared spectroscopy; x-ray powder diffraction spectroscopy; and elemental analysis of $\mathrm{Na}, \mathrm{Al}$ and $\mathrm{P}$.

The acidic ${ }^{26} \mathrm{Al}-\mathrm{SALP}$ was incorporated into a biscuit, as 1 and $2 \%$ SALP. A baking powder containing $25 \%$ acidic-SALP, $25 \%$ sodium bicarbonate and $50 \%$ corn starch was prepared to model the typical acidic SALP content (21 to $26 \%$ ) of baking powders (Pennington, 1987). This was incorporated into a biscuit, prepared from $90 \%$ wheat flour, $0.8 \%$ salt, $3 \%$ butter, $6 \%$ baking powder and water as necessary. The ${ }^{26} \mathrm{Al}$ concentration in the biscuit was determined as follows. Biscuit ( 20 to $25 \mathrm{mg}$ ) was transferred to $7 \mathrm{ml}$ screw cap Teflon $\circledR$ Tuf-tainers $®$ and 4 mg Al (Aldrich ICP/DCP standard) added. Samples were dried then digested in a 2:1 nitric acid:peroxide mixture. The acid was then diluted 4 times, each a 10-fold dilution, and an aliquot transferred to a porcelain crucible and 4 additional $\mathrm{mg}$ of Al standard added. The sample was then slowly heated to $1000^{\circ} \mathrm{C}$ in a muffle furnace to convert the $\mathrm{Al}$ to $\mathrm{Al}$ oxide. The $\mathrm{Al}$ oxide was analyzed by AMS, as described below. The biscuit containing 1 and $2 \%$ acidic ${ }^{26} \mathrm{Al}-\mathrm{SALP}$ had $0.98 \mathrm{nCi}(51.5 \mathrm{ng})$ or $1.02 \mathrm{nCi}(53.6 \mathrm{ng}){ }^{26} \mathrm{Al}$, respectively. An identical biscuit without ${ }^{26} \mathrm{Al}$, but containing $\sim 1.5 \%$ acidic SALP, was similarly prepared to acclimate and train the rats, as noted below.

\subsection{Animals}


The subjects were 13 male Fisher 344 rats, weighing $322 \pm 32 \mathrm{~g}$ (mean $\pm \mathrm{SD}$ ). Animal work was approved by the University of Kentucky Institutional Animal Care and Use Committee. The research was conducted in accordance with the Guiding Principles in the Use of Animals in Toxicology.

\subsection{Experimental procedures}

The subjects were acclimated to a $10 \%$ protein diet that was designed to minimize food retention in the stomach (Harlan Teklad 95215). They had food access from 08:00 to 18:00 $\mathrm{h}$ daily for $\geq 5$ days prior to the determination of oral Al bioavailability. This diet was shown to result in the absence of food in the stomach $14 \mathrm{~h}$ after its withdrawal when fecal recycling (coprophagia) was prevented by a fecal collection cup, as described (Yokel et al., 2001). In a pilot study, six rats had access to this diet for $10 \mathrm{~h}$ daily for 7 days. Fourteen $\mathrm{h}$ after diet removal, no food was found in their stomachs (Yokel et al., 2001). Drinking water was freely available throughout the study except for the period from $14 \mathrm{~h}$ before to $4 \mathrm{~h}$ after oral dosing.

The rats were conditioned to eat $1 \mathrm{~g}$ of biscuit containing $\sim 1.5 \%$ acidic SALP without ${ }^{26} \mathrm{Al}$ which was presented $14 \mathrm{~h}$ after diet removal daily for $\geq 4$ days. Rats that learned to readily eat the food within 15 min were surgically prepared with venous cannulae to enable blood withdrawal. They were implanted with two femoral venous cannulae 1 day prior to oral dosing. This enabled iv administration through one cannula and blood withdrawal from another, to avoid contamination of withdrawn blood by the administered Al. Precise food consumption was determined by pre-weighing the presented biscuit (to obtain its dry weight) then rigorously recovering from the rat's cage 30 min later the uneaten biscuit, which was dried and weighed. Oral bioavailability calculations were based on the weight of consumed biscuit.

Addition of 1 and $2 \%$ acidic SALP to biscuit was selected to provide two amounts of Al to ascertain if there was dose-dependent absorption and to stay within the maximum use level of $2.5 \%$ for acidic SALP as a leavening agent in baked goods (Pennington, 1987). These 
concentrations were similar to those found in some baked goods or baked good mixes, that had up to $1200 \mathrm{mg} \mathrm{Al} / \mathrm{kg}$, equivalent to $~ 1.4 \%$ acidic SALP (Saiyed and Yokel, 2005).

The subjects were randomly assigned to be given $1 \mathrm{~g}$ biscuit containing 1 or $2 \%$ acidic ${ }^{26} \mathrm{Al}$-SALP ( $\mathrm{n}=5 /$ group), in the absence of food in the stomach. Two control rats similarly received biscuit containing $1.5 \%$ acidic SALP and one rat received intragastric administration of $1 \mathrm{ml}$ of water, without ${ }^{26} \mathrm{Al}$.

Oral Al bioavailability was determined in the un-anesthetized rat. Based on the results of a pilot study, the rats were iv infused at $100 \mu \mathrm{g} \mathrm{Al} / \mathrm{kg} / \mathrm{h}$ to produce an estimated $500 \mu \mathrm{g} \mathrm{Al} / \mathrm{l}$ in blood plasma for the ${ }^{27} \mathrm{Al}$ dose, as described (Yokel et al., 2001). In this study $\mathrm{AlK}\left(\mathrm{SO}_{4}\right)_{2}$ was continuously infused from $14 \mathrm{~h}$ prior to $60 \mathrm{~h}$ after oral dosing. Blood was withdrawn $1 \mathrm{~h}$ prior to and $0,1,2,4,8,24,36,48$ and $60 \mathrm{~h}$ after oral dosing. These sample times were based on two similar studies in which rats were given oral Al solution. In the initial study blood samples were obtained to $120 \mathrm{~h}$. However, only two samples beyond $24 \mathrm{~h}$ met the criteria to be reliably above pre-treatment serum values. Therefore, the results are essentially based on samples up to $24 \mathrm{~h}$ (Yokel et al., 2001). In the second study blood samples were obtained to $24 \mathrm{~h}$ (Zhou and Yokel, 2006). The sampling times of the present study included 36,48 and $60 \mathrm{~h}$, based on the expectation that $\mathrm{Al}$ absorption from a solid food would be more prolonged than from water. The blood withdrawn $(0.3 \mathrm{ml}$ for the -1 to $4 \mathrm{~h}$ samples, then $0.5 \mathrm{ml}$ for the $8 \mathrm{~h}$ sample, $2.1 \mathrm{ml}$ at $24 \mathrm{~h}$ and $4.1 \mathrm{ml}$ at 36 and $48 \mathrm{~h}$ ), was replaced by an equal volume of injected saline. Additionally, the rats had access to $2 \mathrm{ml}$ water with the biscuit and free water and food (10\% protein diet) beginning $4 \mathrm{~h}$ after dosing. The $60 \mathrm{~h}$ blood sample was obtained by anesthetizing the rat and exsanguination from a femoral cannula and then the heart. Serum was obtained for ${ }^{26} \mathrm{Al}$ and ${ }^{27} \mathrm{Al}$ analysis. Blood urea nitrogen (BUN) and creatinine were determined in the $60 \mathrm{~h}$ sample.

\subsection{Analysis of total Al by electrothermal atomic absorption spectrometry}


A pooled serum sample from untreated rats was rigorously analyzed by the method of additions to determine its ${ }^{27} \mathrm{Al}$ content. Standards containing $\mathrm{Al}$ were prepared from aliquots of this sample, diluted 10 -fold with $0.2 \% \mathrm{HNO}_{3}$ and $2.5 \mathrm{mM} \mathrm{Mg}$ and spiked with known amounts of a commercial analytical ${ }^{27} \mathrm{Al}$ standard. Samples were similarly prepared and analyzed compared to the standards, using a Perkin-Elmer $4100 \mathrm{ZL}$ transversely heated graphite atomizer atomic absorption spectrophotometer vented to the outside air to avoid laboratory contamination with ${ }^{26} \mathrm{Al}$. Standard curves were obtained before and after every ten samples. An aliquot of each serum sample was diluted at least 10 -fold, as above, prior to analysis. All post- ${ }^{26} \mathrm{Al}$-treatment serum samples were repeatedly analyzed until their Al concentration RSD was $<10 \%$, as previously conducted (Yokel et al., 2001).

2.5. Analysis of ${ }^{26} \mathrm{Al}$ by accelerator mass spectrometry (AMS) The procedures were as described by Yokel et al. (2001). 


\subsection{Data analysis}

A criterion for acceptance of post-treatment serum ${ }^{26} \mathrm{Al}$ concentrations considered to be reliably above pre-treatment serum values was established as $>2 \mathrm{SD}$ above the mean pre-treatment serum ${ }^{26} \mathrm{Al}$ concentration. This criterion was $0.31 \mathrm{pg}{ }^{26} \mathrm{Al} / \mathrm{l}$. Values below this criterion are not presented graphically and were not used in the data analysis. This criterion was met by all of the samples obtained except one value at $48 \mathrm{~h}$ and one at $60 \mathrm{~h}$; both were $0.3 \mathrm{pg}{ }^{26} \mathrm{Al} / \mathrm{l}$. The mean half-life of elimination of the ${ }^{26} \mathrm{Al}$, determined using RSTRIP (Fox and Lamson, 1989), was $4.8 \mathrm{~h}$. Therefore, blood was obtained for $>3$ half-lives, which is more than sufficient time to determine the AUC of the ${ }^{26} \mathrm{Al}$. Each subject's pre-treatment serum ${ }^{26} \mathrm{Al}$ concentration was subtracted from its posttreatment values. Oral ${ }^{26} \mathrm{Al}$ bioavailability $(\mathrm{F})$ was calculated as follows and expressed as a percent:

$$
F=\frac{\text { The sum of the trapezoidal areas for }{ }^{26} \mathrm{Al}}{\text { The sum of the trapezoidal areas for }{ }^{27} \mathrm{Al}} \times \frac{{ }^{27} \mathrm{Al} \text { hourly infusion rate } \times \text { time }}{{ }^{26} \mathrm{Al} \text { dose }}
$$

Time to maximum serum ${ }^{26} \mathrm{Al}$ concentration $\left(T_{\max }\right)$ and the maximum concentration $\left(\mathrm{C}_{\max }\right)$ were calculated using RSTRIP.

Unpaired two-tailed t-tests were used to test for differences in the oral bioavailability, $\mathrm{T}_{\max }$ and $\mathrm{C}_{\max }$ of $\mathrm{Al}$ from the $1 \%$ compared to $2 \%$ acidic SALP and from the combined acidic SALP results compared to results of Al absorption from water, which was previously conducted (Yokel et al., 2001; Zhou and Yokel, 2006). For results with significantly different variances a Mann Whitney test was performed. A difference of $P<0.05$ was accepted as statistically significant. 


\section{Results}

The rats given biscuit containing ${ }^{26} \mathrm{Al}-\mathrm{SALP}$ consumed 0.35 to $1.04 \mathrm{gm}$ ( mean $=0.70$ ). Each rat's serum ${ }^{26} \mathrm{Al}$ results were normalized to its ${ }^{26} \mathrm{Al}$ dose. The BUN and serum creatinine values of the rats in this study ranged from 7.4 to 17.8 and from $<0.2$ to $0.4 \mathrm{mg} / \mathrm{dl}$, respectively, well within normal limits ( $<30$ and $1 \mathrm{mg} / \mathrm{dl}$, respectively). The ${ }^{26} \mathrm{Al}$ concentration in the serum samples obtained from all rats prior to ${ }^{26} \mathrm{Al}$ (or ${ }^{26} \mathrm{Al}$ vehicle) dosing ranged from 0 to 0.4 (mean = $0.085) \mathrm{pg} / \mathrm{l}$. The concentration of ${ }^{26} \mathrm{Al}$ in the 8 samples from each of the three non- ${ }^{26} \mathrm{Al}-$ treated rats after vehicle dosing ranged from 0 to $0.6 \mathrm{pg} / \mathrm{l}($ mean $=0.11)$. Therefore, serum from non${ }^{26} \mathrm{Al}$-treated rats did not show appreciable cross-contamination. Peak serum ${ }^{26} \mathrm{Al}$ concentrations after oral ${ }^{26} \mathrm{Al}$ dosing in $1 \%$ acidic SALP ranged from 36.5 to $93.6 \mathrm{pg} / \mathrm{l}$ and after $2 \%$ acidic SALP from 13.9 to $156.3 \mathrm{pg} / \mathrm{l}$. Therefore, the oral ${ }^{26} \mathrm{Al}$ dose increased peak serum ${ }^{26} \mathrm{Al} \sim 160$ - to 1840 fold above mean pre-treatment values. The time courses of serum ${ }^{26} \mathrm{Al}$ following oral ${ }^{26} \mathrm{Al}$ dosing for the two acidic SALP treatment groups are shown in Figure 1. In the 1\% SALP group peak serum ${ }^{26} \mathrm{Al}$ concentration occurred in the $2 \mathrm{~h}$ sample from one rat, the $4 \mathrm{~h}$ sample from three rats, and the $8 \mathrm{~h}$ sample from one rat. In the $2 \%$ SALP group peak serum ${ }^{26} \mathrm{Al}$ concentration was seen in the $2 \mathrm{~h}$ sample from one rat, the $4 \mathrm{~h}$ sample from two rats, and the $8 \mathrm{~h}$ sample from two rats. The percentage of the AUC included in the $A U C_{\text {time to last sample }} / A U C_{\text {infinity }}$ was $>95 \%$ in all cases, indicating that samples were collected for sufficient time to adequately determine oral Al absorption. Oral AI bioavailability and the results of RSTRIP analysis of $T_{\max }$ and $\mathrm{C}_{\max }$ are shown in Table 1. The differences in Al bioavailability, $\mathrm{T}_{\max }$ and $\mathrm{C}_{\max }$ results from $1 \%$ compared to $2 \%$ acidic SALP were not statistically significant. The differences in these measures from the combined $1 \%$ and $2 \%$ acidic SALP data compared to the individual or combined Al bioavailability data from studies of Al absorption from water (Yokel et al., 2001; Zhou and Yokel, 2006) were significant. 


\section{Discussion}

There has been some controversy about the safety of Al in food for nearly a century. Gies (1911) concluded from available studies that the use of Al in food was a dangerous practice. For substances used in foods prior to 1958, the FDA permits expert opinion to be based on a reasoned judgment founded in experience with common food use, taking into account reasonably anticipated patterns of consumption, cumulative effects in the diet, and safety factors appropriate for the utilization of animal experimentation data (FASEB, 1975). A rereview of the GRAS status of Al was conducted, based on the previous review, a review of the published literature, and studies contracted by producers of acidic SALP which was fed to rats and dogs in diets containing up to $3 \%$ for 90 days (FASEB, 1975). The opinion of the FASEB members who conducted the review was that "There is no evidence in the available literature on ...acidic sodium aluminum phosphate [and other Al forms] ... that demonstrates, or suggests reasonable grounds to suspect, a hazard to the public when they are used at levels that are now current or that might reasonably be expected in the future." Although noting that care should be taken by patients with kidney disease when consuming food containing high levels of Al salts, the authors did not mention dialysis encephalopathy, which has been attributed to Al, or the controversial role of Al in Alzheimer's disease. Indeed, the contribution of Al from Al cooking utensils to serum $\mathrm{Al}$ and urinary $\mathrm{Al}$ excretion in patients with chronic renal insufficiency has been demonstrated (Lin et al., 1997).

A central issue in the controversy concerning the safety of $\mathrm{Al}$ in foods is its oral bioavailability. This is the first study to determine oral Al bioavailability from a common specific food component that provides a significant contribution to dietary Al intake.

There have been previous studies addressing the ability of acidic SALP to produce toxicity and to be absorbed. A study conducted by the Stauffer Chemical Company failed to find significant toxicity from acidic SALP (Levair ${ }^{\circledR}$, now marketed by Rhodia) when added to the diet of beagles for six months, at 0.1 and $3 \%$ of the diet. Although females experienced some 
statistically significant reductions in food intake, they were not considered toxicologically significant because there was no corresponding weight reduction. Diagnostic histopathology showed no adverse outcomes (Katz et al., 1984). This study did not determine Al bioavailability or blood or tissue Al concentrations. Oral absorption of Al from a food was demonstrated in guinea pigs that ate a sponge cake containing acidic SALP. It provided $376 \mu \mathrm{g} \mathrm{Al} / \mathrm{g}$; a total of 40 $\mathrm{mg}$ of Al over 3 weeks. They had a significant elevation of bone Al compared to subjects eating only guinea pig chow (Owen et al., 1994).

It might be anticipated that some Al consumed in food would be solubilized in the low $\mathrm{pH}$ of the stomach. This was found in studies of the solubility of Al compounds contained in bread in normal human subject stomach contents, according to Steel (1911) and Smith (1928). Over $75 \%$ of the $\mathrm{Al}$ in corn bread baked with corn having $0.2 \% \mathrm{Al}$ was extracted using $0.3 \% \mathrm{HCl}$ at 37 ${ }^{\circ} \mathrm{C}$ for $12 \mathrm{~h}$ (Myers and Voegtlin, 1914). Approximately $25 \%$ of the Al from Al baking powders used to prepare $\sim 100 \mathrm{~g}$ of biscuit that was eaten by humans was found in a soluble form in the stomach and duodenal contents (Gies, 1911; Myers and Killian, 1928). Soluble Al in the stomach (at pH 1.3 to 1.6 ) and intestine (at $\mathrm{pH} 8.1$ to 8.4 ) of guinea pigs that consumed sponge cake containing acidic SALP was 17 and $0.3 \%$ of the total Al, respectively (Owen et al., 1994). Using an in vitro simulated gastrointestinal digestion procedure to estimate the absorbable fraction of Al from foods, Lopez et al. (2002) concluded it to be 0.85 to $2.15 \%$ from various foods. The solubility of Al in the stomach was also suggested based on Al chemistry, as Al becomes a free ion, with waters of hydration, below $\mathrm{pH} 5$, in the absence of complexing ligands (Harris et al., 1996). As Al forms insoluble Al hydroxide at circum-neutral pH, it may precipitate, inhibiting absorption, when it enters the intestines, as suggested by Reiber et al. (1995). Therefore, it is difficult to predict the extent of oral Al bioavailability. The anticipated low bioavailability of Al from food, based on its low bioavailability from water, makes determination of oral absorption difficult. In light of the ubiquitous presence of Al in the environment and biological organisms, it would require a considerable increase of Al from absorption, and large 
oral exposure, to reliably see an elevation above the background Al concentration. The use of ${ }^{26} \mathrm{Al}$ and $\mathrm{AMS}$ in the present study overcomes this problem.

There have been prior attempts to address oral Al bioavailability from foods. Studies showed measurable amounts of $\mathrm{Al}$ in the blood of dogs fed alum $\left(\mathrm{AIK}\left(\mathrm{SO}_{4}\right)_{2}\right)$ in "meat-hash pills" and biscuits baked with alum baking powder, but not in non-Al fed dogs (Steel, 1911). Similarly, dogs fed a few biscuits containing sodium aluminum sulfate, in the absence or addition of mono calcium phosphate, often had more Al in their blood and tissues than dogs consuming a normal diet (Underhill and Peterman, 1929a). Some humans also showed small increases of Al in blood and urine after consumption of biscuit or griddle cake containing commercial "alum phosphate" baking powder (Underhill and Peterman, 1929b). On the other hand, only a slight increase of tissue Al was seen in rats that consumed $\sim 8 \mathrm{mg} \mathrm{Al} / \mathrm{kg}$ daily in biscuit (Myers and Mull, 1928). A review of balance studies in humans concluded they were not able to determine oral $\mathrm{Al}$ bioavailability from foods, because the percentage absorbed is so low (UK MAFF, 1993). Al bioavailability from diets containing $\sim 5 \mathrm{mg}$ Al daily was estimated, based on urinary Al excretion compared to dietary $\mathrm{Al}$ intake, to be $0.78 \%$ in young human males. When Al lactate was added to the diet to provide $120 \mathrm{mg} \mathrm{Al} /$ day, a similar calculation suggested $\sim 0.09 \% \mathrm{Al}$ absorption (Greger and Baier, 1983). Stauber et al. (1999) estimated Al bioavailability from drinking water and food in humans and found it comparable from these two sources, $\sim 0.3 \%$. Al bioavailability from food was based on $24 \mathrm{~h}$ urinary Al excretion during the second day of consumption of a controlled diet. This diet provided $\sim 3 \mathrm{mg} \mathrm{Al} /$ day, below typical dietary intake. Absorption of $\mathrm{Al}$ from food consumed prior to the study, which likely provided $>3 \mathrm{mg}$ Al/day, may have contributed to the urinary Al excretion during the study because $<50 \%$ of $\mathrm{Al}$ excreted in the urine after ${ }^{26} \mathrm{Al}$ administration appears within the first $24 \mathrm{~h}$ (Priest, 1993; Talbot et al., 1995). Therefore Stauber et al. may have over-estimated dietary Al bioavailability. Oral Al bioavailability from food has been estimated to be $\sim 0.1 \%$ based on average daily urinary $\mathrm{Al}$ excretion compared to average daily Al intake from food (Powell and Thompson, 1993; Priest, 
1993; Nieboer et al., 1995). The results of the present study are consistent with previous total diet studies and estimates.

The present study did not find an effect of the Al dose on Al bioavailability, within the range of acidic SALP-concentrations tested. The few studies conducted to date to address the possibility that Al bioavailability is dose-dependent have not resulted in consistent findings.

The later $\mathrm{T}_{\max }$ of $\mathrm{Al}$ from acidic SALP in biscuit observed in the present study, compared to water, is consistent with the apparent site of Al absorption, the upper intestine and delayed gastric emptying of food compared to water (Froment et al., 1989; Nagy and Jobst, 1994; Whitehead et al., 1997). $\mathrm{C}_{\max }$ values were lower after oral consumption of ${ }^{26} \mathrm{Al}$ in biscuit than water, as expected when oral bioavailability is lower and $T_{\max }$ is later.

The present estimate of oral Al bioavailability from a dietary component suggests lower oral Al bioavailability from food than previously reported in studies of water. In a study of 21 humans the estimated oral bioavailability of ${ }^{27} \mathrm{Al}$, present in water from a municipal water treatment facility, was $0.36 \%$ (Stauber et al., 1999). Two studies, each conducted in two humans and utilizing ${ }^{26} \mathrm{Al}$, estimated oral $\mathrm{Al}$ bioavailability to be 0.1 and $0.22 \%$, respectively (Hohl et al., 1994; Priest et al., 1998). These studies determined oral Al absorption from urinary Al excretion. Priest et al. (1998) and Stauber et al. (1999) attempted to correct their estimate of Al oral bioavailability for the fraction of absorbed Al that was not thought to be excreted in the urine during the duration of their studies. In a study in rats given intragastric ${ }^{26} \mathrm{Al}$ in the absence and presence of food in the stomach, and with or without added calcium and magnesium to model hard drinking water, oral Al bioavailability averaged $0.28 \%$ (Yokel et al., 2001). A replication of this study, in the absence of food in the stomach or added calcium and magnesium to the water, showed oral Al bioavailability to be $0.29 \%$ (Zhou and Yokel, 2006).

In summary, the bioavailability of Al from this representative food was significantly less than from water, when comparing studies using very similar experimental methods. The results of this study of oral Al bioavailability from acidic SALP in a biscuit suggest $\sim 0.1 \%$ of the $\mathrm{Al}$ was 
orally absorbed. A prior study and a recent replication of that study, using the same methods (Yokel et al., 2001; Zhou and Yokel, 2006), suggested $\sim 0.3 \%$ of Al was orally absorbed from water. As noted in the Introduction, food and water provide $\sim 5$ to $10 \mathrm{mg}$ and $0.1 \mathrm{mg}$ of Al, respectively, to typical daily $\mathrm{Al}$ intake by humans. The products of their $\mathrm{Al}$ contribution to the diet $\times$ the absorbed percentage of $\mathrm{Al}$ (for food: 5 to $10 \mathrm{mg}$ of $\mathrm{Al} \times 0.1 \%$ absorption, delivering $7.5 \mu \mathrm{g}$ of Al to systemic circulation daily; for water: $0.1 \mathrm{mg} \mathrm{Al}$ daily $\times 0.3 \%$ absorption, delivering 0.3 $\mu \mathrm{g}$ ) suggest food provides $\sim 25$-fold more Al to systemic circulation than does drinking water. This suggests food provides considerably greater potential to contribute to an Al body burden than does drinking water. 


\section{Acknowledgement:}

This work was supported by NIH Grant R01 ES11305. 


\section{References:}

Alfrey, A. C., LeGendre, G. R., Kaehny, W. D., 1976. The dialysis encephalopathy syndrome. Possible aluminum intoxication. N. Engl. J. Med. 294, 184-188.

Bushinsky, D. A., 1997. Bone disease in moderate renal failure: cause, nature and prevention. Annu. Rev. Med. 48, 167-176.

FASEB (Federation of American Societies for Experimental Biology), 1975. Evaluation of the health aspects of aluminum compounds as food ingredients, $26 \mathrm{pp}$, U.S. FDA Report FDA/BF-77/24, NTIS-PB 262655.

Flarend, R., Elmore, D., (1998). Aluminum-26 as a biological tracer using accelerator mass spectrometry. In: Aluminum toxicity in infant's health and disease (P. Zatta, A. C. Alfrey, eds.), pp. 16-39. World Scientific, Singapore, London.

Fox, J.L., Lamson, M.L., 1989. RSTRIP: pharmacokinetic data stripping/least squares parameter optimization, ver. 5. MicroMath, Salt Lake City, UT.

Froment, D. P., Molitoris, B. A., Buddington, B., Miller, N., Alfrey, A. C., 1989. Site and mechanism of enhanced gastrointestinal absorption of aluminum by citrate. Kidney Int. 36, 978-984.

Gies, W. J., 1911. Some objections to the use of alum baking-powder. JAMA. 57, 816821.

Greger, J. L., Baier, M. J., 1983. Excretion and retention of low or moderate levels of aluminium by human subjects. Food Chem. Toxicol. 21, 473-477.

Gupta, V. B., Anitha, S., Hegde, M. L., Zecca, L., Garruto, R. M., Ravid, R., Shankar, S. K., Stein, R., Shanmugavelu, P., Rao, K. S. J., 2005. Aluminium in Alzheimer's disease: Are we still at a crossroad? Cell. Mol. Life Sci. 62, 143-158.

Harris, W. R., Berthon, G., Day, J. P., Exley, C., Flaten, T. P., Forbes, W. F., Kiss, T., Orvig, C., Zatta, P. F., 1996. Speciation of aluminum in biological systems. J. Toxicol. Environ. Health. 48, 543-568. 
Hohl, C., Gerisch, P., Korschinek, G., Nolte, E., Ittel, T. H., 1994. Medical application of ${ }^{26}$ Al. Nucl. Instrum. Methods Phys. Res. Sect. B 92, 478-482.

Humphreys, S., Bolger, P. M., (1997). A public health analysis of dietary aluminium. In: Aluminium toxicity in infants' health and disease (P. F. Zatta, A. C. Alfrey, eds.), pp. 226-237. World Scientific, Singapore, Singapore.

Katz, A. C., Frank, D. W., Sauerhoff, M. W., Zwicker, G. M., Freudenthal, R. I., 1984. A 6-month dietary toxicity study of acidic sodium aluminium phosphate in beagle dogs. Food Chem. Toxicol. 22, 7-9.

Kawahara, M., 2005. Effects of aluminum on the nervous system and its possible link with neurodegenerative diseases. J. Alzheimers Dis. 8, 171-182.

Lin, J. L., Yang, Y. J., Yang, S. S., Leu, M. L., 1997. Aluminum utensils contribute to aluminum accumulation in patients with renal disease. Am. J. Kid. Dis. 30, 653-658.

Lopez, F. E., Cabrera, C., Lorenzo, M. L., Lopez, M. C., 2002. Aluminum levels in convenience and fast foods: in vitro study of the absorbable fraction. Sci. Total Environ. 300, 69-79.

Martyn, C. N., Barker, D. J., Osmond, C., Harris, E. C., Edwardson, J. A., Lacey, R. F., 1989. Geographical relation between Alzheimer's disease and aluminum in drinking water. Lancet. i, 59-62.

McDonald, G. A., (1951). Alkali metal aluminum and alkali metal iron acid phosphates as baking acids. U.S Patent 2550490, Victor Chemical Works, US.

Müller, M., Anke, M., Illing-Günther, H., 1998. Aluminium in foodstuffs. Food Chem. 61, 419-428.

Myers, C. N., Voegtlin, C., 1914. Soluble aluminum compounds. Their occurance in certain vegetable products. Public Health Rep. 29, 1625-1629.

Myers, V. C., Killian, J. A., 1928. The solubility in the stomach and duodenum of aluminum compounds found in baking powder residues. J. Biol. Chem. 78, 591-594. 
Myers, V. C., Mull, J. W., 1928. The influence of the administration of aluminum upon the aluminum content of the tissues, and upon the growth and reproduction of rats. J. Biol. Chem. 78, 605-613.

Nagy, E., Jobst, K., 1994. The kinetics of aluminium-containing antacid absorption in man. Eur. J. Clin. Chem. Clin. Biochem. 32, 119-121.

Nieboer, E., Gibson, B. L., Oxman, A. D., Kramer, J. R., 1995. Health effects of aluminum: a critical review with emphasis on aluminum in drinking water. Environ. Rev. 3, 29-81.

Owen, L. M., Crews, H. M., Bishop, N. J., Massey, R. C., 1994. Aluminium uptake from some foods by guinea pigs and the characterization of aluminium in in vivo intestinal digesta by SEC-ICP- MS. Food Chem. Toxicol. 32, 697-705.

Pennington, J. A., Schoen, S. A., 1995. Estimates of dietary exposure to aluminium. Food Addit. Contam. 12, 119-128.

Pennington, J. A. T., 1987. Aluminium content of foods and diets. Food Addit. Contam. 5, 161-232.

Powell, J. J., Thompson, R. P., 1993. The chemistry of aluminium in the gastrointestinal lumen and its uptake and absorption. Proc. Nutr. Soc. 52, 241-253.

Priest, N. D., 1993. The bioavailability and metabolism of aluminium compounds in man. Proc. Nutr. Soc. 52, 231-240.

Priest, N. D., Talbot, R. J., Newton, D., Day, J. P., King, S. J., Fifield, L. K., 1998. Uptake by man of aluminium in a public water supply. Hum. Exp. Toxicol. 17, 296-301.

Reiber, S., Kukull, W., Standish-Lee, P., 1995. Drinking water aluminum and bioavailability. J. AWWA. (J. Am. Water Works Assoc.) 87, 86-100.

Saiyed, S. M., Yokel, R. A., 2005. Aluminium content of some foods and food products in the USA, with aluminium food additives. Food Addit. Contam. 22, 234-244. 
Smith, E. E., 1928. Aluminum compounds in food, including a digest of the report of the Referee board of scientific experts on the influence of aluminum compounds on the nutrition and health of man. 378 pp, P.B. Hoeber, Inc., New York.

Stauber, J. L., Florence, T. M., Davies, C. M., Adams, M. S., Buchanan, S. J., 1999. Bioavailability of Al in alum-treated drinking water. J. AWWA. (J. Am. Water Works Assoc.) 91, 84-93.

Steel, M., 1911. On the absorption of aluminium from aluminized food. Am. J. Physiol. 28, 94-102.

Talbot, R. J., Newton, D., Priest, N. D., Austin, J. G., Day, J. P., 1995. Inter-subject variability in the metabolism of aluminium following intravenous injection as citrate. Hum. Exp. Toxicol. 14, 595-599.

UK MAFF (United Kingdom Ministry of Agriculture Fisheries and Food)., 1993. Aluminium in food. The thirty ninth report of the Steering Group on Chemical Aspects of Food Surveillance. Food Surveillance Paper No. 39. 48 pp. + 3 appendices. HMSO (Her Magesty's Stationery Office), London.

Underhill, F. P., Peterman, F. I., 1929a. Studies in the metabolism of aluminium. II. Absorption and deposition of aluminium in the dog. Am. J. Physiol. 90, 15-39. Underhill, F. P., Peterman, F. I., 1929b. Studies in the metabolism of aluminium. III. Absorption and excretion of aluminium in normal man. Am. J. Physiol. 90, 40-51.

Whitehead, M. W., Farrar, G., Christie, G. L., Blair, J. A., Thompson, R. P., Powell, J. J., 1997. Mechanisms of aluminum absorption in rats. Am. J. Clin. Nutr. 65, 1446-1452. Yokel, R. A., 2000. The toxicology of aluminum in the brain: A review. NeuroToxicology. 21, 813-828.

Yokel, R. A., McNamara, P. J., 2001. Aluminum toxicokinetics: An updated mini-review. Pharmacol. Toxicol. 88, 159-167. 
Yokel, R. A., Rhineheimer, S. S., Brauer, R. D., Sharma, P., Elmore, D., McNamara, P, J. 2001. Aluminum bioavailability from drinking water is very low and is not appreciably influenced by stomach contents or water hardness. Toxicology. 161, 93101.

Yokel, R. A., Urbas, A. A., Lodder, R. A., Selegue, J. P., Florence, R. L., 2005. ${ }^{26}$ Alcontaining acidic and basic sodium aluminum phosphate preparation and use in studies of oral aluminum bioavailability from foods utilizing ${ }^{26} \mathrm{Al}$ as an aluminum tracer. Nucl. Instr. Meth. Physics Res. Sec. B. 229, 471-478.

Zhou, Y., Yokel, R. A., 2006. The effect of citrate, maltolate and fluoride on oral ${ }^{26} \mathrm{Al}$ absorption. Exp. Biol., Abstract 710.5, San Francisco, CA. 
Table 1. Oral Al bioavailability when dosed as 1 or $2 \%$ acidic SALP in biscuit or in water, and absorption $T_{\max }$ and $C_{\max }$. Values are mean $\pm S D$

\begin{tabular}{|l|l|l|l|}
\hline & \multicolumn{1}{|c|}{$\begin{array}{c}1 \% \text { SALP } \\
\text { in biscuit }\end{array}$} & \multicolumn{1}{|c|}{$\begin{array}{c}\text { in SALP } \\
\text { in biscuit }\end{array}$} & \multicolumn{1}{|c|}{ Water $^{\mathrm{a}}$} \\
\hline Sum AUC for po ${ }^{26} \mathrm{Al}(\mathrm{pg} / / \mathrm{h})$ & $767 \pm 457$ & $692 \pm 554^{\mathrm{b}}$ & $\begin{array}{l}4999 \pm 1884 \\
5260 \pm 1301^{\mathrm{c}}\end{array}$ \\
\hline Sum AUC for iv ${ }^{27} \mathrm{Al}(\mu \mathrm{g} / / / \mathrm{h})$ & $33367 \pm 32253$ & $18290 \pm 9544^{\mathrm{b}}$ & $\begin{array}{l}20363 \pm 19668 \\
24959 \pm 7377\end{array}$ \\
\hline Oral Al bioavailability (\%) & $0.11 \pm 0.11$ & $0.13 \pm 0.12^{\mathrm{b}}$ & $0.28 \pm 0.18$ \\
& & & $0.29 \pm 0.11^{\mathrm{c}}$ \\
\hline $\mathrm{T}_{\max }(\mathrm{h})$ & $4.2 \pm 1.2$ & $6.0 \pm 1.7^{\mathrm{b}}$ & $1.7 \pm 1.1$ \\
& & & $1.2 \pm 0.9^{\mathrm{c}}$ \\
\hline $\mathrm{C}_{\max }(\mathrm{g} / \mathrm{l}$ serum) & $54 \pm 25$ & $54 \pm 42^{\mathrm{b}}$ & $584 \pm 313$ \\
& & & $659 \pm 195^{\mathrm{c}}$ \\
\hline $\mathrm{C}_{\max }(\%$ of dose/ml serum) & $0.00015 \pm 0.000064$ & $0.00012^{2} \pm 0.000082^{\mathrm{b}}$ & $0.00097 \pm 0.00090$ \\
& & & $0.0013 \pm 0.0004^{\mathrm{c}}$ \\
\hline
\end{tabular}

${ }^{a}$ Results from (Yokel et al., 2001; Zhou and Yokel, 2006). These studies also used male Fisher 344 rats; 19 weighing $280 \pm 42 \mathrm{gm}$ (Yokel et al., 2001) and 5 weighing $268 \pm 18 \mathrm{gm}$ (Zhou and Yokel, 2006). These results are based on samples collected 1, 2, 4, 8, 24, and (2 samples only) at $72 \mathrm{~h}$ (Yokel et al., 2001) and 0.25, 0.5, 0.75, 1, 1.25, 1.5, 2, 4, 8 and $24 \mathrm{~h}$ after oral dosing (Zhou and Yokel, 2006).

${ }^{\mathrm{b}}$ Not significantly different from $1 \%$ SALP in biscuit results.

${ }^{\mathrm{c}}$ The results of each study and the combined results were significantly different from the combined results from 1 and $2 \%$ SALP in biscuit. 
Figure legend:

Figure 1. Concentration of ${ }^{26} \mathrm{Al}$ in serum versus time after consumption of ${ }^{26} \mathrm{Al}$ that had been incorporated into acidic SALP which was included in a biscuit containing $1 \%$ (squares) or $2 \%$ (circles) acidic ${ }^{26} \mathrm{Al}-\mathrm{SALP}$. The values are mean \pm SD from 5 rats in each group. 
Figure 1.

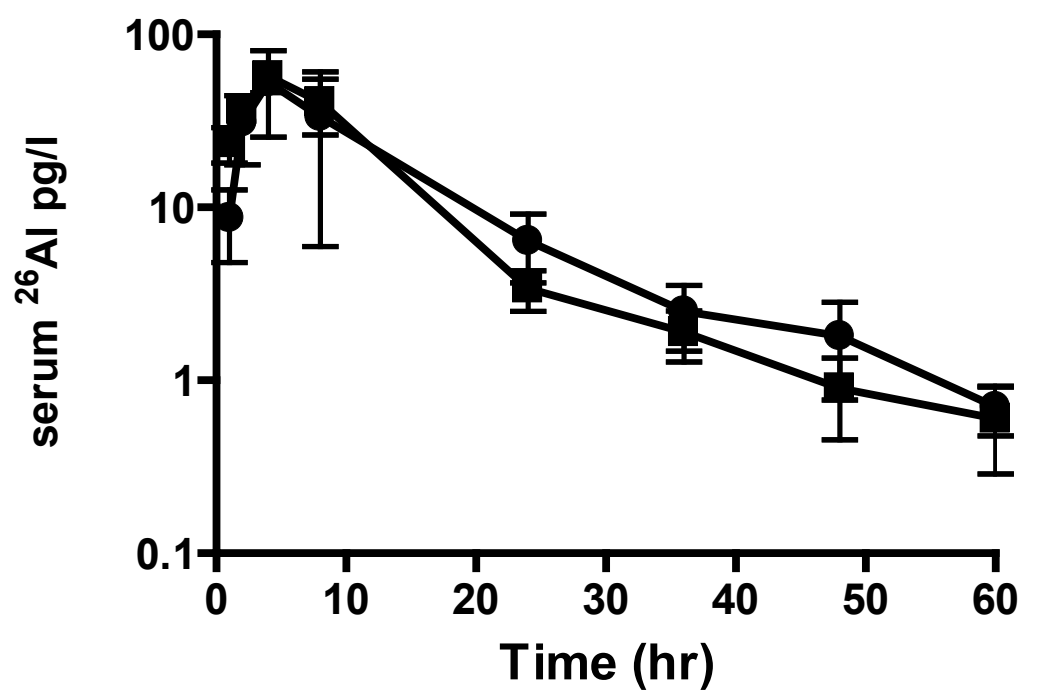

